\title{
The networks at work in the commitments of mathematician Charles-Ange Laisant
}

\author{
Jérôme Auvinet
}

Published online: 20 January 2015

(c) Centro P.RI.ST.EM, Università Commerciale Luigi Bocconi 2015

\begin{abstract}
The present article deals with some of the involvements of the French mathematician Charles-Ange Laisant (1841-1920). It describes the various themes linked to the career of this rather unknown mathematician, from equipollencies and quaternions and the foundation of mathematical journals, to the international congresses of mathematicians, to his involvement in mathematics teaching. For each of them, the author describes the scientific communities involved: how Laisant interacts with each of these different groups, in order to defend particular mathematical theories; how he gets in them to realize his plans, including concretizing his internationalism. As a member of several networks, he tries to improve the communication between scientists at the beginning of the twentieth century. As a member of parliament, he offers an interesting example of a mathematician who is driven by his political convictions. His goal is to improve society as a whole through science and a more modern education.
\end{abstract}

Keywords Charles-Ange Laisant · 19th-century mathematics - Networks of mathematicians - Diffusion of equipollences · Mathematics teaching - "éducation nouvelle" · Mathematical journals · International congresses of mathematicians

\section{Introduction}

Along with the great mathematicians known and acclaimed by all, it is also interesting to study the strategies of those

J. Auvinet $(\bowtie)$

Laboratoire de Mathématiques Jean Leray, 2 Rue de la Houssinière, BP 92208, 44322 Nantes Cedex 3, France

e-mail: auvinet_jerome@yahoo.fr who have been forgotten, at least partially, by history. There are many-perhaps very many-such figures within the community of mathematicians, and their work often reveals unknown aspects of the scientific society in a given period.

The example of French mathematician Charles-Ange Laisant (1841-1920) is instructive in this regard. A man of networks, he was at the crossroads of several communities of mathematicians with different characteristics (Fig. 1). Further, he himself furthered innovative projects for the entire mathematical world. The multiplicity of routes that he followed make it possible to see, through each of his careers, his strong commitment to the science of his day. His commitment can be seen when in his choices of the side to take in order to defend with conviction or endorse a certain theory, or more generally to give mathematics it proper role in society. However, in parallel he was also engaged in activities of promoting or provoking projects of importance for the mathematical community. He thus provides an original image of a mathematician committed to this community and who encourages other players to undertake certain projects, some of which are still operative today, all framed within a specific conception of science [1].

We will first examine the methods adopted by Laisant to defend the two main chapters of his mathematical work: geometrical calculus, consisting here of the theories of equipollencies and quaternions, and number theory. His activism for the dissemination of these disciplines extended to strong convictions about their teaching. We will then discuss Laisant's international involvement and various concrete projects he set up or supported to encourage communication between scientists on various topics related to the debates ongoing at the time. Finally, the mathematician is inseparable from his opinions about society, in 


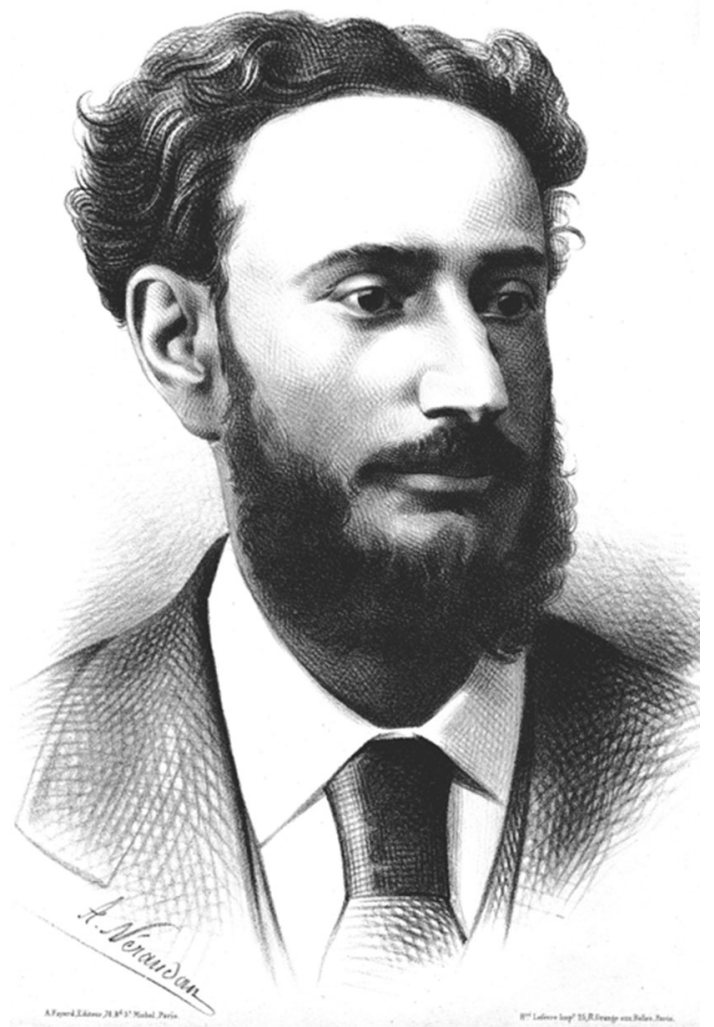

Fig. 1 Charles-Ange Laisant (1841-1920). Image courtesy of the author

which science plays a large role, notably through the education of each individual. We will thus underline the political dimension that Laisant strove to give mathematics through the ideas that he championed regarding its teaching at the dawn of the twentieth century.

\section{Promoting new mathematical research}

After finishing the École polytechnique, where he was admitted in 1859, Laisant's career as mathematician and captain in the army corps of engineering seems to have been hampered by the many changes that distanced him from the great scientific centres, as he explains in a letter to the Minister of War dated July 1873, and that to a certain extent isolated the mathematical community, at least the institutionalised milieus. His first mathematical writings (on arithmetic and infinitesimal geometry) remained relatively confined to the requirements of the entrance examinations to schools such as the École polytechnique, and logically appeared in a journal of mathematics called "intermediate", Nouvelles Annales de mathématiques (NAM), a journal mainly aimed at the candidates of those examinations.
His true career as a mathematician began when he devoted himself energetically to the theory of equipollencies of the Italian Giusto Bellavitis (1803-1880) (Fig. 2), the dissemination of which is often credited to him.

Laisant began a lengthy correspondence with Bellavitis thanks to a professor at the faculty of Bordeaux, Jules Houël (1823-1886), another great promoter of the work of Bellavitis and close to Laisant. When the geometer and senator from Padua wrote his theory in 1832, he complained of the scant interest it aroused, even in Italy, and in spite of his having published a number of works on the question, in particular his Sposizione del metodo delle equipollenze in 1854. This is the work that Laisant translated 20 years later to make geometric calculus known in France. That translation, Exposition de la méthode des équipollences (1874), was circumscribed by the fact that French science tended to ostracise and ignore the mathematics practiced by foreigners. Its aim was the dissemination of a general method which establishes a direct calculation of the geometric objects of the plane or space themselves by establishing operations on the lines comparable to those of algebra, in accordance with the desire expressed at the beginning of the century, mainly by Carnot. Laisant's involvement is marked by a large concern for fidelity, visible in his correspondence with Bellavitis, and in Bellavitis's exhortations to maintain the purely geometric nature of equipollencies. Laisant explains:

Instead of artificially interpreting the analytical expressions meaningless in themselves, Bellavitis, in creating the method of equipollencies, has established an notation and a doctrine that is applied to the

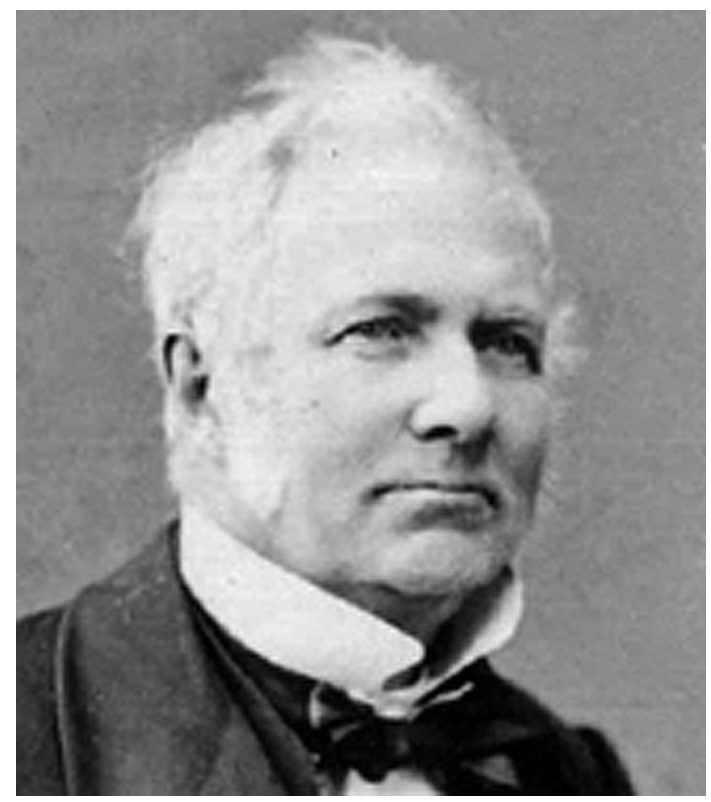

Fig. 2 Giusto Bellavitis (1803-1880) 
geometrical facts of an absolute reality and clarity. Further, trying to combine these geometrical elements, he has found himself led to a calculus in which the rules are identical with those of the imaginary quantities of algebra. ... In a form that is somewhat concise, but nevertheless exact, one can say that the calculus of equipollencies is the natural algebra of the geometrical facts of the plane. ${ }^{1}$

Laisant defended this essential aspect of the theory, notably on the occasion of the congress of the Association Française pour l'Avancement des Sciences (AFAS), for example against Ernest Laquière, during an exchange following Laquière's communication entitled "Sur l'origine géométrique de la méthode des équipollences" (1881). The congresses of that association, founded in 1872 following the defeat at Sedan, as part of a movement for the promotion of science that was organised at the beginning of the Third Republic, represented one of the main venues (along with the new $N A M$ ) that Laisant chose for popularising equipollencies, by means of several articles. For a broad and diverse audience he chose to make the calculus of Bellavitis known by means of numerous applications (in kinematics, the theory of curves, the new triangular geometry) in order to best show its interest, simplicity and generality. The desire to multiply the range of applications of the method characterises Laisant's strategy as an active disseminator of equipollencies. His activism was equally aimed at making Bellavitis's theory penetrate into French secondary teaching, as appears particularly in his second work on the subject, Théorie et applications des équipollences (1887). Here he reprises the translation of 1874 and appropriates its mode of exposition, integrating it and reorganising his own writings on the applications of equipollencies, all the while insisting on the methodological aspect of the theory. He writes:

As in 1874, I am persuaded that the method of equipollencies can render a very great service to a large number of questions, and that it deserves to be transmitted in teaching. ... It is this above all that made me decide to make this new attempt. ${ }^{2}$

\footnotetext{
${ }^{1}$ Au lieu d'interpréter artificiellement des expressions analytiques dépourvues de sens par elles-mêmes, Bellavitis, en créant la méthode des équipollences, a établi une notation et une doctrine s'appliquant à des faits géométriques d'une réalité et d'une clarté absolues. Puis, cherchant à combiner ces éléments géométriques, il s'est trouvé conduit à un calcul dont les règles sont identiques avec celles des quantités imaginaires de l'algèbre. ... Sous une forme un peu concise, mais cependant exacte, on peut dire que le calcul des équipollences est l'algèbre naturelle des faits géométriques du plan ([9], p. 153).

2 Comme en 1874, je suis persuadé que la méthode des Équipollences peut rendre de très grands services dans un grand nombre de questions, et qu'elle mérite de passer dans l'enseignement ... C'est surtout ce qui m'a décidé à faire cette nouvelle tentative ([8], p. V).
}

His wish would come partially true with the great reform of secondary teaching of 1902, and the appearance of vector calculus in the programs of mathematics and physics.

The effort spent by Laisant to make equipollencies known naturally extended to the theory of quaternions, which he considered to be a natural extension of Bellavitis's ideas about space. In his first work, Applications mécaniques du calcul des quaternions (1877) [6], to the writing of his own treatise, Introduction à la méthode des quaternions (1881) [7], in which he sets out for a large readership the "algebra of geometric facts of space", the operative mode of promotion consists in multiplying the range of applications after having first reprised the original writings on the question (in this case, the mechanical works of Hamilton) While the venue for dissemination is different, mainly the Société mathématique de France (SMF) and much more rarely the Académie des Sciences, the pedagogical ambitions for this other geometric calculus remained unchanged. In effect, Laisant writes:

In spite of the many advantages, the calculus of quaternions has not yet penetrated deeply in France.

A small number of curious spirits have studied it, and

use it with profit; but in no part and to no degree has

this method assumed a place in teaching. ${ }^{3}$

Equipollencies and quaternions formed the main focusses of Laisant's interest in the years 1872-1887. These two aspects of a genuine geometrical calculus thus constitute his first involvement with the promotion in France of the results obtained by a foreigner. The pedagogical visions of that work of dissemination would turn out to be increasingly relevant, even if they embraced only much later Grassmann's more modern theory of extensive magnitudes.

While a part of the French mathematical community was aware of its autarchy with regard to foreign mathematics, and particularly after the defeat at Sedan, Laisant found himself relatively alone in spreading geometrical calculus. Only his friend Houël, an important translator of work on non-Euclidean geometry, shared the same direction as Laisant. This relative isolation in the propagation of quaternions was nevertheless lightened when he joined the International Association for Promoting the Study of Quaternions and Allied Systems of Mathematics in 1899. While the objectives of this group, which disbanded after a short time, appear not to have been met, the contacts established among those who were dealing with these

\footnotetext{
${ }^{3}$ Malgré tant d'avantages, le calcul des quaternions n'a pas encore pénétré profondément en France. Un petit nombre d'esprits curieux l'ont étudié, et s'en servent heureusement; mais nulle part, à aucun degré, cette méthode n'a pris place dans l'enseignement ([10], p. 1120).
} 
questions (Hathaway, Stockes, Tait, Peano, Laisant and others) proved significant. This confirms Laisant's adoption to a new perspective on the role of international and institutional exchanges in the promotion of these methods.

Laisant's choice to devote his mathematical works to the dissemination of the theories of Bellavitis and Hamilton gave way little by little in the 1890 s to another focus of interest: that of the questions of numbering, arithmetic, number theory and geometry of position, which are grouped under the term "discrete mathematics". The strategies adopted to treat these themes shows once again a very precise methodology: he acted mainly by first putting the graphic illustration, the visual representation of the notions by means of checkerboards, tables of numbers or other schematics. Inspired by the work of Édouard Lucas (1842-1891), author of a Théorie des nombres published in 1891 and a guiding light at that time, as Bellavitis and Houël had been earlier, Laisant developed, for example, his "mosaic" to represent the various multiplicative systems, or dealt with the "tables of sums" beginning with generalisations of Pascal's triangle. Beyond the mathematical treatment adopted, what is remarkable is his promotion of an entire chapter of mathematics that had been neglected by the academic milieu of which he wasn't part.

That commitment to seeing the development of discrete mathematics in France took on as many forms as the complementary networks to which the mathematician belonged (AFAS and SMF, for example). One of the most remarkable was that related to his political career. Elected a member of parliament from 1876 to 1893 , his career as a statesman is marked by intransigent positions: from the opposition to the opportunists to his Boulangist activism in passing, among others, the reform of military service. It was then during his term as a member of parliament that he campaigned first for the publication of the works of Fermat in 1882 and then for the creation of a chair in number theory at the College de France during the years 1887-1888. Because that discipline was explicitly studied in Germany and Laisant was aware of the pivotal role of teaching positions, he reported to the National Assembly during the session of 25 January 1887:

At a certain time number theory was an eminently French science: after a certain number of years that branch of science was cultivated in foreign nations, Germany above all, with extraordinary care. This made it, on their part, the object of considerable work. At the same time, it must be said and must be verified with regret, number theory was abandoned in France. As I speak, in all of the foreign universities around [us], in Russia, in Italy, in Germany, in England, important works on numbers are being made in that branch of science; there are chairs in those countries, where it is taught and learned. At the same time, and by now for a long time, there is no chair in France, not a single one where number theory is taught. 4

The intersection between the careers of statesman and mathematician is striking here: a sitting member of parliament of the radical left, in a spirit of scientific patriotism, Laisant considers this evolution of secondary teaching to be an imperative necessity for the science of his country. Castigating existing teaching, anticlerical as he was, he incurred the wrath of the Catholic Hermite, and went against the judgment of the Académie des Sciences. The National Assembly became the scene of the other true commitment of the mathematician, who was marginalised from the institutional milieu and did not succeed in joining the Académie des Sciences in 1907.

With his career marked by discrete mathematics, the figure of Laisant also affords us a clearer view of the panorama of the French mathematical landscape in his day. In effect, he collaborated with the mathematicians who were outside of the traditional professional context. Supporting the works of Henri Auguste Delannoy (1833-1915) and Gabriel Arnoux (1831-1913), Laisant appears as an essential member of a group of mathematicians of diverse horizons, often amateurs, who, although widely represented at the congresses of the AFAS, were outside its scope. The original exchanges between those unsung mathematicians on various problems over and above what they offer Laisant, illustrates another aspect of that commitment to promoting discrete mathematics within a network.

\section{Fostering exchanges between mathematicians}

Buoyed by the relationships that Laisant gradually created with scientists overseas, the exchanges between scholars become an important topic of reflection for him. He thus advanced the idea of a multinational union for cooperation

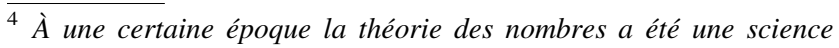
éminemment française; depuis un certain nombre d'années cette branche de la science a été cultivée chez les nations étrangères, par les Allemands surtout, avec un soin extraordinaire. Elle a fait, de leur part, l'objet de travaux considérables. En même temps, il faut le dire et il faut le constater à regret, la théorie des nombres était abandonnée en France. À l'heure où je parle, dans toutes les universités étrangères à peu près, en Russie, en Italie, en Allemagne, en Angleterre, des travaux importants et nombreux sont faits dans cette branche de la science; des chaires existent dans ces pays, où on l'enseigne et où on l'apprend. À cette même heure, et depuis longtemps déjà, il n'y a pas une chaire en France, pas une seule où s'enseigne la théorie des nombres (Annales de la Chambre des députés, $4^{\text {ème }}$ législature, session ordinaire de 1887, t. 1, imprimerie et librairie du journal officiel, Paris, 1887, p. 182).
} 
between mathematicians, the "Universal International Association of Mathematicians". He describes how the objectives of this project would take the form of annual meetings:

... establish a moral and scientific tie between all those who cultivate pure and applied mathematics in today's world ... provide them with the means and occasions to enter more easily into personal relationships with each other. ${ }^{5}$

The idea goes back to 1891 and appears not to have attracted attention. Nevertheless, when his friend at the École polytechnique Émile Lemoine (1840-1912) proposed to him in 1894 the founding of a new mathematical review, L'Intermédiaire des mathématiciens, Laisant saw it as an opportunity to concretise his proposition. The object of that journal was initially to put in direct relation mathematicians, regardless of their origins or statutes, on the most diverse subjects, by a strict principle of questions and answers. It would also serve as a pertinent support for the implementation of an international project shared by Laisant, Lemoine and the German Georg Cantor.

The basis of the relationship between Laisant and Cantor was mathematics: their first epistolary exchange [4] was on the Goldbach conjecture and it was in relation to this that Laisant invited his German colleague to participate in the AFAS congress of 1894, an invitation that is remarkable for being the only one given to a German scientist (until 1914) to a meeting of the Association, marked by the trauma of Sedan. In a short time it was the question of how to organise an international meeting of mathematics that occupied the two men as well as Lemoine. The thorny but crucial question for the success of the project was how to guarantee the support of a great number of mathematicians from several countries at a time when no reputable scientist was willing to become involved with an enterprise that nationalist tensions threatened to topple at any time. The Intermédiaire, with an international readership, was thus to serve to recruit supporters and make the project known to scientists the world over, without its actual initiators putting themselves forward. Laisant and Cantor then undertook, in their respective countries, a vast campaign in favour of the international congress. The fact that Laisant moved in various scientific circles in France (AFAS, SMF, of which he was president in 1888, as well as the Société Philomathique de Paris) meant that he was particularly well-placed to give the project a good deal of exposure.

\footnotetext{
5 ...établir un lien moral et scientifique entre toutes les personnes qui cultivent les mathématiques pures et appliquées dans le monde aujourd'hui, [...] leur fournir les moyens et les occasions d'entrer plus facilement en relation personnelle les unes avec les autres (quoted in [2], p. 82).
}

The activation of numerous networks appears characteristic of Laisant's commitment to internationalism.

While he was relatively isolated at the beginning of the 1890s in his enterprise, Laisant joined a group of scientists who shared the same aspirations: it is the action of this group that ensured the success of the congress in Zurich in 1897 (Fig. 3).

The constitutive meeting lay the foundations for the International Congresses of Mathematicians. To ensure their survival, Laisant extended his involvement during the first Congress and voted, with the help of Cantor, Gabriel Oltramare (1816-1906) and Alexander Wassilieff (Aleksandr Vasil'ev, 1853-1929), for a decision establishing a standing committee, which ensured a positive continuity between congresses. Pragmatically, he was also involved in practical work discussed at this meeting, by publishing in 1902 an Annuaire des mathématiciens, a directory of mathematicians aimed at gathering contact information for all practitioners of mathematics on the planet. Laisant thus appears to have been an important protagonist in this project for an international congress as well as a figure in its actual implementation.

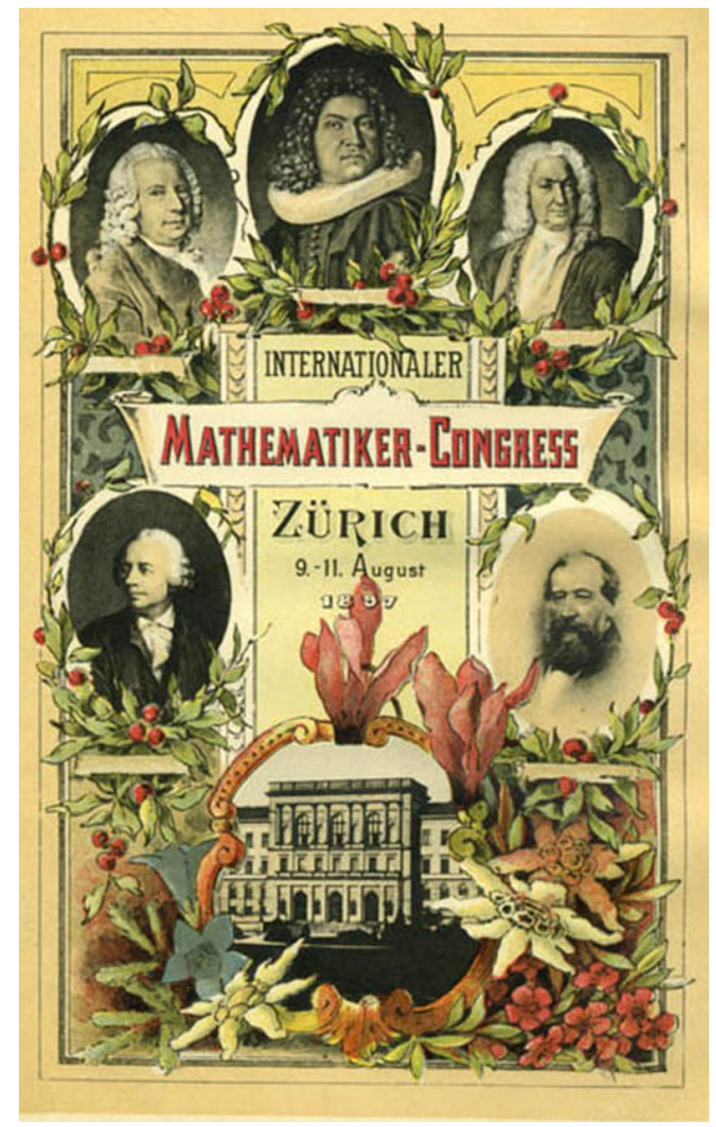

Fig. 3 Poster publicising the International Congress of Mathematicians held in Zurich in 1897 
This "great movement of scientific solidarity", as he seductively described it, also found another concrete realisation, in the domain of teaching. When the Swiss Henry Fehr (1870-1904) proposed that he found a journal dedicated to questions of mathematics teaching, Laisant, at first reticent, suggested that the publication be given a "highly international" character in order to assure its success. The constitution of an editorial board of that journal then occupied an important part of their correspondence, and in 1899 L'Enseignement mathématique appeared. The first mathematical journal with an explicitly international character dealt with questions of secondary teaching and responded to a debate then ongoing in several countries about the reforms to be made. For this the journal offered an overview of, among other things, the existing conditions of teaching in different countries. The directors, Laisant and Fehr, aimed ambitiously at "overcoming the obstacles that hinder the reciprocal communications and create a kind of mutual, continuous correspondence between men who have consecrated their lives to a noble mission: the mathematical education of young people". 6 The journal thus crystallized a new network for its founder, through which the many French and foreign mathematicians could exchange ideas about mathematics teaching.

These internationalist aspirations are also reflected in Laisant's desire to see the establishment of an international language like Esperanto. His defense of Esperanto took multiple forms: he read a note by Charles Méray, entitled "Sur la langue internationale de M. le Dr Zamenhof, connue sous le nom de «Espéranto»" to the Paris congress in 1900, and in 1908 gave a lecture with universalist and pacifist overtones, entitled "L'Espéranto et l'avenir du monde". It is interesting to observe that his position as director of several journals made it possible for him to extend his actions. As the head of the Nouvelles Annales de mathématiques, L'Intermédiaire des mathématiciens and L'Enseignement mathématique, Laisant never missed an opportunity to emphasise the interest of Esperanto for mathematicians, and invited his authors to use it for this articles, without success:

There is any category of people who should embrace the idea of an international language, it is certainly that of scientists, and in particular of pure mathematicians, where the subjects of study are international par excellence. ${ }^{7}$

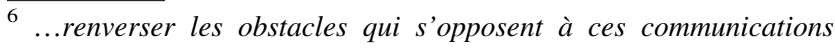
réciproques et de créer une sorte de correspondance mutuelle continue, entre les hommes qui ont consacré leur vie à cette noble mission: l'éducation mathématique de la jeunesse ([14], p. 2).

7 S'il est une catégorie de personnes que doit toucher l'idée de la langue internationale, c'est assurément celle des savants et en particulier des mathématiciens purs, dont les sujets d'étude sont internationaux par excellence [11].
}

It was also thanks to these journals that he became part of an Esperanto-speaking network of mathematicians, principally through his collaboration with Carlo Bourlet (1866-1913) and Charles Méray (1835-1911), both leading figures in the 1902 reform of secondary teaching in France.

Thanks to his role in promoting the international language, and the libertarian convictions that subtended it, Laisant created a network that intersected all the others and linked his commitment to a larger reflection on the society of his day. His enthusiasm for internationalism provides a breathtaking panorama of the networks that he belonged to, as one of his most important commitments, which derived from both a conception of the evolution of mathematics and of the functioning of the scientific community, as well as a profound desire to see society progress as a whole.

\section{Creating societal progress through education}

Laisant's reflections on society were expressed throughout his career as a statesman, which frequently intersected with his career as a mathematician. Disappointed by the ineffectiveness of parliament, he gave up political life in 1893 . He then began a career in teaching that would lead him to become an examiner at the École polytechnique beginning in 1899. It is thus principally to the education of young people that he devoted a new part of his work. This new commitment is explained by his desire for reform, whose principal lever is the progress of the education of the working classes.

Buoyed by his reflections on "mathematic", which he included in a work entitled La Mathématique. Philosophie. Enseignement published in 1898, he posed as the founding principle the necessity of inculcating in each child the basis of a genuine scientific education that would allow access to an indispensable mathematical culture. In 1906 he published a book "foreign to all programs, dedicated to friends of childhood", entitled L'Initiation mathématique, in which he proposed, in 65 lessons, to give children 6 years old the simplest notions (numeration, operations on integers, fractions) as well as more complicated notions (function, analytical geometry, conics). By refraining from any dogmatic approach, he based himself on a playful and novel approach which relied on the learner's natural curiosity, visualisation and the concretisation of the notions treated, offering a "guide" for educators, and in particular for mothers, to "liberate childhood". He concludes by stating that "mathematical initiation is indispensable for all children, without any distinction as to wealth, social standing, gender". 8

\footnotetext{
8 ...l'initiation mathématique est indispensable à tout enfant, sans aucun distinction de fortune, de situation sociale, de sexe [13]. For the influence of this work in Italy, see ([3]).
} 
With this groundbreaking work, the first of a book series entitled "Collection des Initiations" that he directed and which included other scientific disciplines as well (astronomy, chemistry, mechanics) following the same pedagogical and didactic principles, Laisant joined the movement called "new education" that developed beginning in the 1890s. He became a harsh critic of the French educational system that perpetuated social inequality. He wanted to see this substituted by a truly secular school, that is, one without any ideology, and proposed an integral and rational education based on scientific data. This new commitment is represented by Francisco Ferrer i Guàrdia (1859-1909) (Fig. 4), the Catalan pedagogue who founded the Escuela moderna in Barcelona, who Laisant met during his visit to Paris in 1901.

The two men, both Freemasons, shared a number of ideas on reforms to be made and the short-lived journal L'École rénovée (1908-1909) directed by Ferrer published a number of articles by Laisant. There again Laisant formed a new network composed of thinkers, teachers and trade unionists. This publication also allowed the founding, in 1908, of the International League for Rational Childhood Education, a year before the execution of Ferrer, which he passionately opposed. In December 1907 he wrote regarding the League:

All reasonable men, whose interest have not strayed, cannot deny the necessity of giving childhood an education in keeping with the psychological state of the child, based on science and rational in the broadest sense of the term, that is to say, free from all dogma of any discipline. The question is posed in the same form, the problem to be solved is the same everywhere. Your appeal must be met with an enormous success the world over. It is only at this price that the painful convulsions that the future has in store for humanity will be mitigated, if not avoided. ${ }^{9}$

Sébastien Faure (1858-1942) was another friend of Laisant's in this period. Founder of the libertarian school La Ruche, and member of the International League of Rational Education founded by Francisco Ferrer, Faure led Laisant towards anarchical positions through the intervention of his son. The positions of the elderly deputy became even more radical with the publication of $L a$ Barbarie

\footnotetext{
9 Tous les hommes raisonnables, que l'intérêt n'égare pas, ne peuvent méconnaître la nécessité de donner à l'enfance une éducation conforme à son état psychologique, s'appuyant sur la science, et rationnelle dans le sens le plus large du mot, c'est-à-dire dégagée de tout dogme en toute matière. La question se pose sous la même forme, le problème à résoudre est le même partout. À votre appel doit répondre une acclamation formidable dans le monde entier. C'est à ce prix seulement que seront atténuées, sinon évitées, les convulsions douloureuses que l'avenir réserve à l'humanité (quoted in [5], p. 121).
}

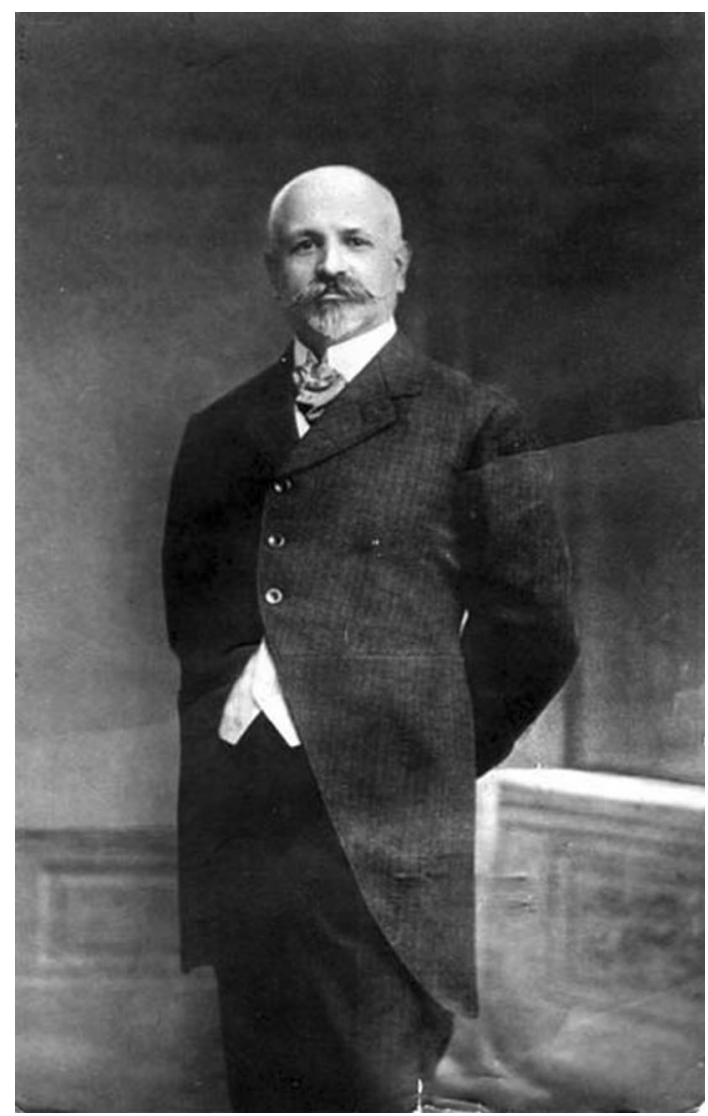

Fig. 4 Francisco Ferrer i Guàrdia (1859-1909)

moderne in 1912. Faure was a fervent defender of Dreyfus, as was Naquet, Laisant's political companion since the days of Boulangism. For his part, Laisant might appear removed from the revisionist movement, although he had this to say about military justice in La Barbarie moderne: "The Dreyfus affair has made it possible to modify the full depth of the shame, the whole absurdity of this institution", ${ }^{10}$ and in retrospect supported the deposed captain.

With the outbreak of World War I in 1914, the libertarian Laisant signed a document that caused a brutal fracture within the anarchist movement. The Manifeste des Seize (Manifesto of the Sixteen (signed by sixteen figures, including Pierre Kropotkine and Jean Grave) condemned the German aggression and indicated clear support for the Allies, justifying military action:

In our profound conscience, Germany's attack was a threat, not only against our hopes of emancipation, but against all human evolution. That is why we, anarchists, we, antimilitarists, we, enemies of war, we, passionate partisans of peace and of fraternity of the people, we have sided with resistance and believe

\footnotetext{
${ }^{10}$ L'affaire Dreyfus a permis de mesurer toute la profondeur de honte, toute l'absurdité de cette institution ([12], p. 133).
} 
we must not separate our fate from that of the population. $^{11}$

Is this perhaps the vengeful spirit of the former caption of the army corps of engineers who showed brilliantly in the battle of 1870 ? Is it a profound fatalism that struck when his health declined after 1913, the year he retired from his positions at the École polytechnique, when his mathematical activities were reduced? The internationalist seems to flinch in the face of the challenges of World War I, breaking with the pacifist ideals that he had embraced through Esperanto.

\section{Conclusion}

The causes championed by Laisant-mathematician, man of politics, thinker and pedagogue-appear to be as numerous and audacious as they are inseparable from the networks to which he belonged. Sometimes isolated at the beginning of his work, he joined various groups who shared his projects. The interactions between his commitments and his network of correspondents is noteworthy. Some communities were born of new impetus given by the mathematician. Others already formed turned out to be adequate venues of expression for his various objectives. These were more of less institutionalised, driven by the journals that he founded or directed, the communities to which Laisant belonged were all of support to his commitments, although so very diverse. The mathematician forged his career by following several pathways that intertwined and intersected, each marked by a strong choice, all progressively liked to a desire for social progress. His speech as President of the AFAS in 1904 was entitled "The Social Role of Science". In spite of the errors in his political thinking, his commitments were driven by a profound republicanism, by a form of scientism that existed at the time, and more precisely by faith in the progress of society through education and science.

Translated from the French by Kim Williams.

\footnotetext{
${ }_{11}$ En notre profonde conscience, l'agression allemande était une menace - mise à exécution - non seulement contre nos espoirs d'émancipation, mais contre toute l'évolution humaine. C'est pourquoi nous, anarchistes, nous, antimilitaristes, nous, ennemis de la guerre, nous, partisans passionnés de la paix et de la fraternité des peuples, nous nous sommes rangés du côté de la résistance et nous n'avons pas cru devoir séparer notre sort de celui du reste de la population (Manifeste des Seize, 28 February 1916).
}

\section{References}

1. Auvinet, J.: Charles-Ange Laisant. Itinéraires et engagements d'un mathématicien, d'un siècle à l'autre (1841-1920), tesi di dottorato sotto la direzione di Évelyne Barbin, Épistémologie et histoire des sciences et des techniques, Université de Nantes (2011)

2. Brigaglia, A., Masotto, G.: Il circolo matematico di Palermo, Dedalo, p. 82 (1982)

3. Conti, A.: Sull'iniziazione alle matematiche e sulla preparazione matematica dei maestri elementari in Italia. Atti del IV Congresso Internazionale dei Matematici, pp. 519-528 (1908)

4. Décaillot. A.-M.: Cantor et la France. Correspondance du mathématicien allemand avec les Français à la fin du $\mathrm{XIX}^{\mathrm{e}}$ siècle, éditions Kimé (2008)

5. Ferrer, S.: La vie et l'œuvre de Francisco Ferrer. Un martyr au $\mathrm{XX}^{\mathrm{e}}$ siècle. Librairie Fischbacher, Paris (1962)

6. Laisant, C.-A.: Applications mécaniques du calcul des quaternions : Sur un vouveau mode de transformation des courbes et des surfaces. Gauthier-Villars, Paris (1877)

7. Laisant, C.-A.: Introduction à la méthode des quaternions. Gauthier-Villars, Paris (1881)

8. Laisant, C.-A.: Théorie et applications des équipollences. Gauthier-Villars, Paris (1887)

9. Laisant, C.A.: Equipollence (1892). In: Berthelot, M., et al. (eds.) La Grande Encyclopédie, vol. 16, p. 153. Lamirault, Paris (1885)

10. Laisant, C.A.: Quaternion (1885-1902). In: Berthelot, M., et al. (eds.) La Grande Encyclopédie, vol. 27, p. 1120. Lamirault, Paris (1900)

11. Laisant, C.A.: L’Espéranto et les mathématiques, Nouvelles Annales de mathématiques, sér. 4, vol. 3, pp. 337-339 (1903)

12. Laisant, C.A.: La Barbarie moderne. La Bataille Syndicaliste, Paris (1912)

13. Laisant, C.A.: L'Initiation mathématique, $15^{\text {ème }}$ ed., Librairie Hachette (1916)

14. Laisant, C.A., Fehr, H.: Préface: aux lecteurs de "L'Enseignement mathématique", L'Enseignement mathématique, t. 1, p. 2 (1899)

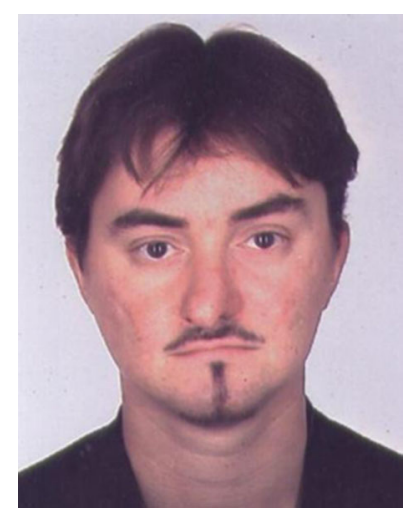

Jérôme Auvinet earned his $\mathrm{Ph} . \mathrm{D}$. from the University of Nantes with a thesis entitled "Charles-Ange Laisant. Itinéraires et engagements d'un mathématicien, d'un siècle à l'autre (1841-1920)" under the advisement of Evelyne Barbin. This research enabled him to take into account several aspects of the mathematical community, in France but also in Europe, at the turn of the twentieth century. For this reason his interests concern the dissemination of mathematical theories, the mathematical journals of this time, the modes of communication between scientists and mathematical education. A point shared by these topics is that they make it possible to underline how a biographical work about the careers of a mathematician, even one who is rather unknown, can shed light on some particular aspects of a scientific community. This work is linked to his membership in the research group on history of mathematics in the Laboratoire Jean Leray of the University of Nantes. 